\title{
CORRIGENDUM
}

\section{Nrf2-dependent persistent oxidative stress results in stress-induced vulnerability to depression}

E Bouvier, F Brouillard, J Molet, D Claverie, J-H Cabungcal, N Cresto, N Doligez, C Rivat, KQ Do, C Bernard, J-J Benoliel and C Becker

Molecular Psychiatry (2017) 22, 1795; doi:10.1038/mp.2016.211; published online 1 November 2016

Correction to: Molecular Psychiatry advance online publication, 20 September 2016; doi:10.1038/mp.2016.144

This article was originally published under NPG's License to Publish, but has now been made available under a CCL ND 4.0 license. The PDF and HTML versions of the paper have been modified accordingly.

\begin{abstract}
This work is licensed under a Creative Commons Attributionc) (1) (5) $)$ NonCommercial-NoDerivs 4.0 International License. The images or other third party material in this article are included in the article's Creative Commons license, unless indicated otherwise in the credit line; if the material is not included under the Creative Commons license, users will need to obtain permission from the license holder to reproduce the material. To view a copy of this license, visit http:// creativecommons.org/licenses/by-nc-nd/4.0/
\end{abstract}

(c) The Author(s) 2017 